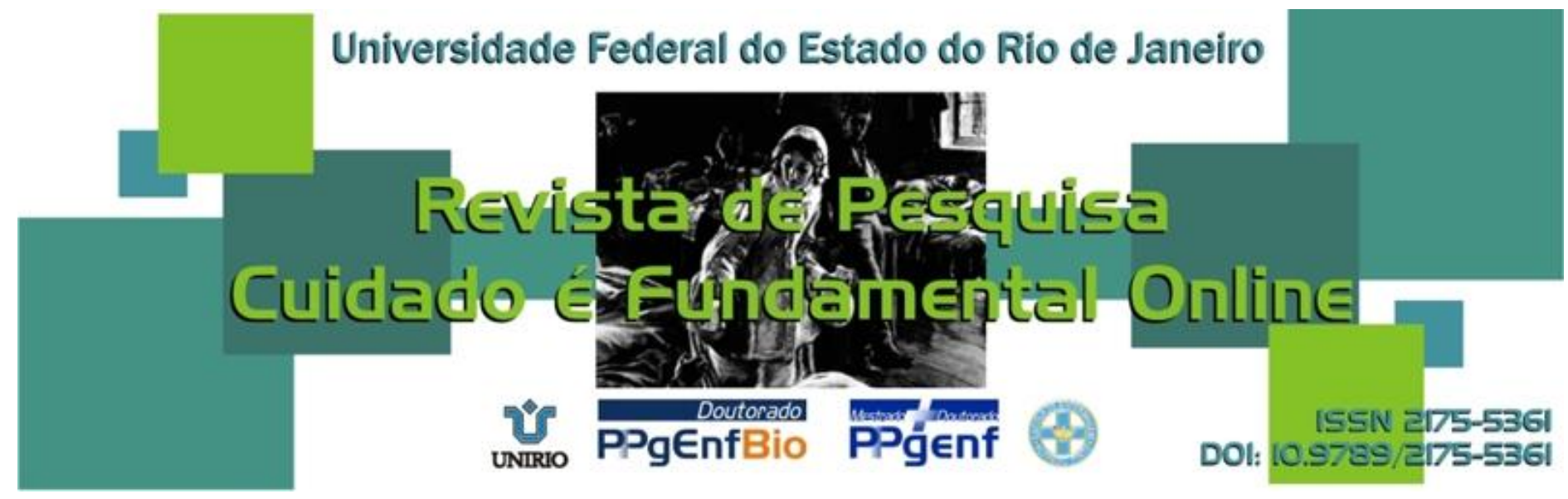

RESEARCH

\title{
INVESTIGATING THE AGED POPULATION OF TANGUÁ CITY: THE PROFILE OF THE FREQUENTERS OF A HEALTH POLYCLINIC
}

\author{
INVESTIGANDO A POPULAÇÃO IDOSA DO MUNICÍPIO DE TANGUÁ: O PERFIL DOS FREQUENTADORES DE UMA \\ POLICLÍNICA DE SAÚDE
}

\section{INVESTIGANDO LA POBLACIÓN ANCIANA DE LA CIUDAD DE TANGUÁ: EL PERFIL DE LOS FRECUENTADORES DE UNA POLICLÍNICA DE SALUD}

Julianne Quinellato Louro ${ }^{1}$, Edmundo de Drummond Alves Junior ${ }^{2}$, Fátima de Lima Paula ${ }^{3}$, Hugo Leonardo Prata ${ }^{4}$, Jéssica Janete Novaes Santos ${ }^{5}$, Elciana Vieira ${ }^{6}$

\begin{abstract}
Objective: Describe the profile of the aged users of a health polyclinic of the Tanguá city, Rio de Janeiro. Method: Transversal, descriptive study. It was used as an instrument for data collection a questionnaire, participating 180 elderly. Results: There was in interviewed population a prevalence of the feminine sex, low education and the majority lived with family; regarding to health data, $25 \%$ and $56.6 \%$ consider its health as good or reasonable, respectively, even those with confirmed diseases, being the arterial hypertension the illness most prevalent. Conclusion: The mapping of the characteristics of older people from a particular region contributes to the understanding of aging Brazilian, as well as new directions for public policy. Descriptors: Health profile, Aged, Aging.
\end{abstract}

\section{RESUMO}

Objetivo: Descrever o perfil dos idosos usuários de uma policlínica de saúde do município de Tanguá, RJ. Método: Estudo transversal, descritivo. Utilizou-se como instrumento de coleta de dados um questionário, participando 180 idosos. Resultados: Houve na população entrevistada uma prevalência do sexo feminino, baixa escolaridade, e a maioria convivia com a família; em relação aos dados de saúde, $25 \%$ e $56,6 \%$ consideram respectivamente sua saúde como boa ou razoável, mesmo apresentando quadro de doença confirmada, sendo a hipertensão arterial a doença mais prevalente. Conclusão: 0 mapeamento das características dos idosos de uma dada região contribui para o entendimento do envelhecimento brasileiro, como também para novos direcionamentos de políticas públicas. Descritores: Perfil de saúde, Idoso, Envelhecimento.

\section{RESUMEN}

Objetivo: Describir el perfil de los usuarios ancianos de un policlínica de la salud de la ciudad de Tanguá, RJ. Método: Estudio transversal, descriptivo. Un cuestionario fue utilizado como instrumento de la colecta de datos, participando 180 ancianos. Resultados: Tenía en la población entrevistada una prevalencia femenina, escolaridad baja y la mayoría vivió con la familia; en lo referente a los datos de la salud, los $25 \%$ y $56.6 \%$ consideran su salud como buena o razonable respectivamente, mismo presentando el cuadro de enfermedad confirmado, siendo el hipertensión arterial la enfermedad más frecuente. Conclusión: El mapeo del carácter de las personas mayores de una determinada región contribuye a la comprensión del envejecimiento brasileño, así como para nuevas orientaciones de las políticas públicas. Descriptores: Perfil de Salud, Anciano, Envejecimiento.

\footnotetext{
${ }^{1}$ Bachelor of Physical Education, Federal University of Rio de Janeiro; Master's Academic Master of Science in health care from the Federal Fluminense University. E-mail: jullyqlouro@hotmail.com. ${ }^{2}$ Teacher $\mathrm{Dr}$ of the Department of Physical Education and Academic Program Master of Science in Health Care, offered by the School of Nursing, both from Federal Fluminense University. Email: edmundodrummond@uol.com.br. ${ }^{3}$ PhD. in Epidemiology and Master of Public Health from the National School of Public Health-FIOCRUZ, Specialization in Interdisciplinary Gerontology and Geriatrics Fluminense Federal University, Graduate in Physiotherapy By Helena Antipoff Superior School and Civil Engineer from the University Gama Filho. E-mail: fatima.lima.paula@gmail.com. ${ }^{4}$ Professor of Physical Education; PhD in Science of Education from the National University of Córdoba. Professor of Physical Education of the State University of Rio de Janeiro. E-mail: hugo.prata@uol.com.br. ${ }^{5}$ Master of Science in Health Care, a specialist in Gerontology and Geriatrics Interdisciplinary Fluminense Federal University, Graduate Physiotherapy from the University Estacio de Sá. E-mail: jj15172024@yahoo.com.br. ${ }^{6}$ Master of Science in Health Care Federal Fluminense University, a specialist in Human Anatomy and Biomechanics from the University Castelo Branco, Professor of Physical Education from the University Salgado de Oliveira. E-mail: elcianavieira@yahoo.com.br.
}

R. pesq.: cuid. fundam. online 2013. abr./jun. 5(2):3894-03 


\section{INTRODUCTION}

The projections for the aging population in the world and Brazil continue to expand, and if they do not get to be alarming, at least are worrying as regards the future of generational relations, a fact that certainly will influence public policy observed by both social aspect as public health. ${ }^{1-2}$

Brazil already has an amount of people over sixty years approaching twenty million people reaching $10.6 \%$ of the population with a strong uptrend this social group. This results from the demographic transition that has been occurring for some time, confirming the trends of reductions in mortality and fertility have verified in previous censuses.

There are significant changes related to aging, is the social aspect, biological and psychological, which ultimately generates demands, such as those related to social inequality, poverty, chronic illness, functional limitations, lack of autonomy, hospitalizations. As we noted, a set of problems that previous generations had not so strongly as now. This not only affected the social relations but also regarding the relationship with the family, not to mention the responsibilities to be assumed by public agencies and policies to meet that fit into what we call the elderly. Social group that, in Brazil, fit people aged over 60 years.

By inserting aging as one of the social problems of the moment, academia also began researching the topic and their results eventually contributed to a greater understanding of the demands of this social group. Studies on the health variables that interfere in a stale quality are of paramount importance to guide public policies aimed at promoting health. ${ }^{4}$

Apply efforts to solve problems of population health is investing in the development and adequate access to health care, it must have R. pesq.: cuid. fundam. online 2013. abr./jun. 5(2):3894-03 public health strategies that allow the elderly to enjoy a more active aging, in which there is recognition of the rights of elderly and the principles of independence, dignity, selfrealization and assistance. Thus, the actions are not based solely on need, which would lead to a more passive posture of the elderly, but rely on the responsibility of individuals to exercise their political roles, in addition to other roles in the community to which they belong. ${ }^{6}$

However, it is good that relativize the search for active aging without a critical access to the population as a whole, makes not always what is proposed is in accordance with the principles that guide what is called health promotion. $6 \mathrm{~A}$ critical analysis of generalization and almost imposition of aging assets as collateral for a different life can be found in the publication "The Pastoral active aging".

Although physical activity positively influence health, autonomy, quality of life and well-being, while also serving to maintain the independence and autonomy of the elderly, one should be very cautious with the statement, and sometimes imposition of "active aging". In this model the individual becomes responsible for their good or bad choice of a way of life more or less active. Thus, successful aging, shall relate directly to the fact of being physically active, imposing a way of life, which is often not applicable to a significant portion of the population. ${ }^{7}$

Maintaining independence and autonomy, as well as functional capacity, become the main goals of an aging considered healthier. This receives a contribution in engaging in various kinds of activities, especially those that require more power and occur through bodily practices. Therefore, a more active way of life, respecting the autonomy of the individual, including the physical exercise as an important element for 
Louro JQ, Junior EDA, Paula FL et al.

stimulating the preservation of physical, mental and social. ${ }^{8}$

In order to improve the health and quality of life, assessment of health conditions and indicators of quality of life of the elderly, is needed so that they can plan effective policy. Policies serve as preventive investment basic health and are more economical than treatment of a disease or a condition associated with aging.

The Brazilian public health system is in the basic service the space where the user can more toward policy proposals aimed at promoting health. To investigate them have strong clues to better understand the population, as these public spaces are found in most municipalities in the country with similar care. For these reasons justify the central idea of the research that has come to be held in one of the municipalities of the State of Rio de Janeiro which has one of the lowest human development index (HDI). ${ }^{10}$

The mapping of the profile of elderly users of a polyclinic in the city of Tanguá may favor the orientation of actions in health, besides indicating local needs. This type of research becomes one of the main instruments to be used for the formulation and evaluation of public policies, while allowing the prevalence of chronic diseases, restrictions (temporary or permanent) caused by these activities and corresponding use services of a public nature. Knowledge of the characteristics of older adults in a given region can contribute to the definition of specific actions, directed the demands of the region. The mapping of the elderly population is of paramount importance, since there is still a lack of information about the health of the elderly population. Therefore, the objective of this study is to describe the profile of elderly users of health polyclinic located in the municipality of Tanguá, state of Rio de Janeiro.

R. pesq.: cuid. fundam. online 2013. abr./jun. 5(2):3894-03
Investigating the aged...

\section{METHODOLOGY}

This transversal study, descriptive was conducted at the Center for Specialty Joseph Pellegrino (CEJP) located in Tanguá, municipality in the last census showed a population of 30,732 inhabitants, 3,320 of those above sixty years. 13 The HDI has been calculated at 0.722 municipality that the municipality does occupy the position 82 of a total of 91 municipalities in the State of Rio de Janeiro. ${ }^{14}$

The study population was comprised of 180 seniors who were consulted in the geriatric sector CEJP in 2011 between the months of February and August. We included those who were consulted and they are manifested according to investigative proposal, which sought to better understand this group of regulars. All who were involved, after being informed of the research objectives signed the Free Clarification research. We excluded those who were unable to answer the questionnaire, whether for reasons of mental development or difficulty understanding the questions asked.

The polyclinic investigated was chosen after observations made by the team of researchers that involved over a period of initial survey remained in the county where the observing public health units had the best conditions for the collection of data. The selection took into account the location of the central CEJP and the existence in it of a sector destined to geriatric care. During the inquiries is also identified that the CEJP was the public health unit who received a greater number of elderly regulars.

In the team who was applying the questionnaire, the four interviewers were previously trained by the Research Group Aging and Physical Activity, Fluminense Federal University. These investigators attended the post during the period of 6 months at times that coincided with the offer of assistance from the geriatricians CEJP. The 
Louro JQ, Junior EDA, Paula FL et al.

instrument is included in the model presented in structured form, containing an open question designed to fulfill the medicines used by the users surveyed. At the time of the survey were collected socio-demographic data as well as some healthrelated variables. The study complied with the ethical criteria and was approved by the Ethics Committee at the Hospital Antonio Pedro-UFF / Niterói, Rio de Janeiro on the protocol number 097/2010.

\section{RESULTS AND DISCUSSION}

The study population characteristics presented as shown below.

Socioeconomic characteristics:

Of the 180 seniors surveyed were all residents of the city, 72 men and 108 women, thus presenting a predominance of females $(60 \%)$. The average age of respondents was 69.50 years with a standard deviation of 6.45 years, with a median age of 69 years. When stratified by sex, the average age for men was 70.92, while for women the mean age came to be 68.56 years and, with the median respectively 70 and 68 years (Table 1 ).

Table 1: Characteristics of stratification by gender of users of health polyclinic located in the municipality of Tanguá -2011

\begin{tabular}{llllll} 
Variable & Average & Median & $\begin{array}{l}\text { Standard } \\
\text { deviation }\end{array}$ & N $\%$ \\
\hline Gender & & 70 & 6,70 & 72 & 40 \\
Men & 70,92 & 68 & 6,14 & 108 & 60 \\
Women & 68,56 & 69 & 6,45 & 180 & 100 \\
Total & 69,50 & & & &
\end{tabular}

\section{Source: Data Collection Instrument}

With regard to education of the regulars, 60 subjects reported not able to read or write, 55 did not have the full primary, but claimed to read and write. Another 50 came to the conclusion the old primary, 9 the old gym and 6 which
Investigating the aged...

corresponds to what is now the middle school. It can be observed that the distributions of education by sex, men and women, the proportions were similar to other studies.

Another issue relates to social observed the living arrangements of the population investigated, and it was found that the fact of living solitarily happens with $20 \%$ (36), and the remaining $80 \%$ (144) reside with relatives.

\section{Health characteristics}

The health was assessed from selfassessment. Thus, considering the fact be in a reasonable state of health was reported by $56.6 \%$ of those investigated, even though $90.5 \%$ of respondents had some medical diagnosis already detected by the post. It was found that $92.2 \%$ users are continuous medication, with $44.44 \%$ of them make use of four or more drug (polypharmacy). When asked about urinary leakage, a fact for which in many cases is not given the necessary attention, it was found that $38.85 \%$ suffer from this problem (Table 2 ).

Table 2: Absolute and percentage frequency of the selfassessment and health conditions of the elderly respondents. Tanguá, 2011.

\begin{tabular}{lll}
\hline Health assessment & $\mathbf{n}$ & $\%$ \\
Self-assessment of health & 45 & 25 \\
Good & 102 & 56,6 \\
Reasonable & 32 & 17,7 \\
Bad & 1 & 0,5 \\
No answer & & \\
Use of medicines & 166 & 92,2 \\
Yes & 14 & 7,7 \\
No & & \\
Polypharmacy & 80 & 44,44 \\
Yes & 100 & 55,55 \\
No & & \\
Diagnostic confirmed of illness & 163 & 90,55 \\
Yes & 17 & 9,44 \\
No & & \\
Urinary Incontinence & 70 & 38,88 \\
Yes & 109 & 60,55 \\
No & 1 & 0,55 \\
Do not know & & \\
\hline
\end{tabular}

Source: Data Collection Instrument

We decided to probe the major geriatric diseases and question the existence of diabetes

R. pesq.: cuid. fundam. online 2013. abr./jun. 5(2):3894-03 
Louro JQ, Junior EDA, Paula FL et al.

mellitus, hypertension, Parkinson's disease, epilepsy, hearing loss and osteoporosis. There was thus obtained the prevalence of hypertension 75.5\%, 30.5\% hearing loss, $26.6 \%$ diabetes mellitus, osteoporosis $24.4 \%, 1.66 \%$ and Parkinson was not confirmed the presence of epilepsy.

Regarding the frequency of leaving home (considering this output as a means of locomotion for certain tasks such as shopping, going to church, visiting friends or otherwise do not confuse with the goal of making a physical exercise), 12 individuals reported not leave home on a regular basis, now 8 report out at least once a week, another 23 leaving at least 2 times a week and 137 elderly declared out 3 or more times a week. As regards the practice of regular physical exercise, based on what is suggested as ideal to obtain improved health15 found that the practice of regular physical activity is present in $27.7 \%$ of the group. Of these we find that $10 \%$, or 18 individuals practicing physical exercises at least four times a week. Balance assessment was represented as being good for 55\% of the elderly and the percentage was $35 \%$ of falls in the last year among those evaluated (Table 3 ).

Table 3: Absolute and relative frequency on balance and falls, Tanguá-2011.

\begin{tabular}{lll} 
Life Style & $\mathbf{n}$ & $\%$ \\
\hline Evaluation of balance & 99 & 55 \\
Good & 56 & 31,1 \\
Reasonable & 25 & 13,8 \\
Bad & & \\
Falls in the last 12 months & 117 & 65 \\
None & 30 & 16,6 \\
Once & 23 & 12,7 \\
2 to 3 times & 7 & 3,8 \\
4 or more & 3 & 1,6 \\
Do not know & & \\
\hline
\end{tabular}

Source: Data Collection Instrument
Investigating the aged...

Table 4 presents the results related to instrumental activities of daily living (IADL), pointing to the ability of a person to lead their lives independently, including the ability to make purchases, prepare meals, take care of your home, use transportation, phone, such as managing their own finances and take their medications.

Table 4: Profile of instrumental activities of daily living in absolute values, Tanguá-2011.

\begin{tabular}{lcclc} 
Variables & Yes & No & Năo sabe & Total \\
\hline Public transport & 153 & 26 & 1 & 180 \\
Leaving the House to shop & 152 & 28 & 0 & 180 \\
Prepare your meal & 170 & 10 & 0 & 180 \\
Using the phone & 154 & 26 & 0 & 180 \\
Take your medicines & 170 & 10 & 0 & 180 \\
Manage your money & 169 & 10 & 1 & 180 \\
\hline
\end{tabular}

Source: Data Collection Instrument

\section{Discussion}

It was found that most of the elderly interviewed were female, had lower education being illiterate or without complete primary, lived with the family in relation to health data, consider their health as fair, even showing signs of disease confirmed hypertension being the most prevalent disease. In addition $92.2 \%$ of the population make use of polypharmacy.

Corroborating the findings of this research, the authors point out in their studies that found similar characteristics, thus contributing to the affirmation of the importance of studying the characteristics of the population has been aging. A study conducted in the city of Coronel Fabriciano, MG, whose aim was to describe the profile of the elderly inserted into a community center, presented in their sample of 184 elderly, predominantly female $(88.6 \%)$ and $78.8 \%$ of respondents lived together, although the framework of schooling make a difference, 
Louro JQ, Junior EDA, Paula FL et al.

because it showed a prevalence under seniors who attended the 1st grade complete.

Some hypotheses were proposed to elucidate the question of the predominance of women as higher life expectancy of women, besides the fact that women are more caring, more concerned with health than men, attending more health centers, even for cultural reasons, the woman who is socially / culturally have to take care of the health of children and is most often responsible for taking them to the doctor.

Because today's seniors lived in a time where education was not a priority, presents the apparent number of elderly people with low educational level. 16 The percentage of people with no education or incomplete primary education fell from $65.1 \%$ to $50.2 \% 1$, despite this reduction, the study data are consistent with the results of these findings. Another reason is that this picture is the HDI local index based on three basic dimensions: income, education and health.

Despite the high number of older people who live alone, there has been a progressive increase in the number of people living alone $(9.1 \%$ to $12.1 \%)$ in recent years.

Self-rated health is widely used in epidemiological research, due to its relationship with clinical conditions and with increased risk of subsequent morbidity and mortality, including the biological and psychosocial, representing the general health perception. It should be noted the ease of collection of this data, in addition to showing the rates of $80 \%$ agreement between selfassessment of health status and clinical assessment of the presence or absence of chronic condition. However, in case of certain chronic diseases such as hypertension and diabetes, in which the patient recognizes the problem only after the medical diagnosis, investigations tend to underestimate its prevalence. In the present study, we observed a self-rated health as fair
Investigating the aged...

corroborating the findings of other studies that showed similar characteristics.

The inappropriate use of medication and polypharmacy is a commonplace problem in the elderly population, a problem that worsens with age and are more precarious health conditions of the individual. The use of 4 or more medications exposes the elderly to interactions that can cause complications in their clinical condition. Therefore, the elderly should be informed about the best time to make your product in order to reduce adverse reactions.

Cardiovascular disorders are the leading cause of death worldwide. In Brazil, this phenomenon is also relevant, with numbers similar to international, with values around $25 \%$, establishing a strong correlation between dyslipidemia and increased risk of death. 30 Cardiovascular diseases (CVD) in Brazil victimize annually nearly 200,000 individuals aged over 60 years on $40 \%$ of mortality in this age group. 31 The circulatory diseases killed 236,731 in 2007 and 111,885 seniors in the Southeast. Cardiovascular risks may increase substantially due to dyslipidemia, a disorder of metabolism caused by changes in the levels of serum lipids. Another important involvement in the population is high blood pressure, a fact that can be observed in the population studied where the values were very high, which leads immediately to a necessary attention to this fact when it comes to the elderly population.

Regarding lifestyle, it is important to note that only $27.7 \%$ of the sample are in the situation of physically active despite high rates of chronic diseases, especially hypertension. One should remember that the practice of regular physical activity can reduce the risk of several chronic health conditions.

Another major problem was investigated in this study fall. The fall has been the subject of research among individuals aged 60 years or more,

R. pesq.: cuid. fundam. online 2013. abr./jun. 5(2):3894-03 
Louro JQ, Junior EDA, Paula FL et al.

thanks to the physical damage, emotional and economic problems that it causes in the elderly. The literature is pointing the fall as a dangerous and tragic event for the elderly, since the fall consequences can range from simple scratches to hospitalizations, surgeries and death. It is a consensus among several countries that $30 \%$ of people fall at least once a year, with $10 \%$ of them were aged over 80 years. Two-thirds of seniors who fall, fall again within six months. Within this context, we believe it is important to highlight the socioeconomic issues related to the sample studied, it is known that less privileged socioeconomic populations have negative health indicators.

Thus, the fall is considered a public health problem and the subject of many studies, the results suggest a rate of falls in the elderly population that is very close to that found in the investigated group, where $33.3 \%$ claim to have fallen during the last year.

\section{CONCLUSION}

From the data presented above, we can infer that the mapping of the profile of the elderly is very important for a better understanding of the specific demands of this segment of the population and may contribute to comprehensive actions to elderly health conditions giving those responsible for public health of small municipalities, as was investigated by us. Despite not having been the central focus of the study, we found clues in order to confirm the importance of certain diseases that we perceive is not limited to large urban centers. The incidence of hypertension as of falls suggests that the policy makers of the municipality should invest more in prevention and health promotion, in this sense, a proposal for preventive health should include the modification of eating habits, such as reducing the sodium intake, the practice of physical activity, R. pesq.: cuid. fundam. online 2013. abr./jun. 5(2):3894-03
Investigating the aged...

being one of these preventive measures educational chronic diseases as well as for the maintenance of autonomy and independence among aging.

It is important to note that data from the study population had similar characteristics with earlier research study with the profile of the same nature. Thus, these characteristics point to better understand the needs arising from the aging process in Brazil, contributing to new directions in public policy. We recommend further research in the city, since it has certain peculiarities that deserve to be deepened, whether related to drug use, as the way of life of aging people.

\section{REFERENCES}

1- Brasil. Instituto Brasileiro de Geografia e Estatística. Sinopse censo demográfico 2010, IBGE, 2011. Disponível em: http://www.ibge.gov.br/home/mapa_site/mapa_ site.php\#download acessado em 28/11/2012 as 10:40 hrs.

2- United States Census Buerau. International Programs.2013 (SITE). Disponível em: http://www.census.gov/population/international/ data/idb/region.php acessado em 08/01/2013 as 14:23 hrs.

3- Alves Junior ED. Envelhecimento e vida saudável. 1 ed. Rio de janeiro: Apicuri, 2009.

4- Alves LC, Leite LC, Machado CJ. Perfis de saúde dos idosos no Brasil: análise da Pesquisa Nacional por Amostra de Domicílios de 2003 utilizando o método grade of membership. Cad. Saúde Pública. 2008 mar; 23(3): 535-46. Disponível em: http: / / www.scielo.br/scielo.php?pid=S0102-

311X2008000300007\&script=sci_arttext .

5- Rodrigue RAP, Kusumota L, Marques S, Fabrício SCC, Cruz, IR, Lange C. Política nacional de atenção ao idoso. Rev. Texto e Contexto Enfermagem. 2007;16( 3):536-45. Disponível em: 
Louro JQ, Junior EDA, Paula FL et al.

http: / / www.scielo.br/scielo.php?pid=S0104$07072007000300021 \&$ script=sci_arttext .

6- WHO. Envelhecimento ativo: uma política de saúde. Organização Pan-Americana da Saúde. Brasília: 2005.

7- Alves Junior ED A pastoral do envelhecimento ativo. 1 ed. Rio de janeiro: Apicuri;2011.

8- Shephard RJ. Envelhecimento, atividade física e saúde. São Paulo: Phorte, 2003.

9- Lebrão ML, Laurenti R. Saúde, bem-estar e envelhecimento: o estudo SABE no Município de São Paulo. Rev. Brasileira de Epidemiologia. 2005; 8(2):129-32. Disponível em: http: / / www.scielo.br/scielo.php?script=sci_arttex t\&\%20pid=S1415-790X2005000200005 .

10- Brasil. Informações socioeconômicas do município de Tanguá. Sebrai. Rio de Janeiro:2011.

11- Ishitani LH, Franco GC, Perpetuo, IHOF, França

E. Desigualdade social e mortalidade precoce por doenças cardiovasculares no Brasil. Rev Saúde Pública [online]. 2009;40(4): 684-91. Disponível em: http: / / www.scielo.br/scielo.php?pid=S0034$89102006000500019 \&$ script=sci_arttext .

12- Barros MBA, Cesar CLG, Carandina L , Torre GD. Desigualdades sociais na prevalência de doenças crônicas no Brasil, PNAD-2003. Rev Ciênc. saúde coletiva [online]. 2006;11(4): 911-26. Disponível

em:

http: / /www.scielo.br/scielo.php?pid=S1413-

$81232006000400014 \&$ script=sci_abstract\&tlng=pt .

13- Instituto Brasileiro de Geografia e Estatatística, IBGE cidades. Dados Sociodemográfico. Brasil; 2012. Disponível em: http://www.ibge.gov.br/cidadesat/painel/painel. php?codmun $=330575$ acessado em 28/11/2012 as 10:46 hrs.

14- Brasil. Instituto De Pesquisa Econômica Aplicada - IPEA. Índice de Desenvolvimento Humano - IDH. Rio de Janeiro: 2000. Disponível
Investigating the aged...

em: $\quad$ www.ipeadata.gov.br.acessado em 10/10/2012.

15- ACSM, American College of Sports Medicine. Diretrizes do ACSM para os Testes de Esforço e sua Prescrição. 8ed. Rio de Janeiro: Guanabara Koogan; 2010.

16- Pavarini $\mathrm{SCl}$, Luchesi $\mathrm{BM}$, Fernades $\mathrm{HCL}$, Mendiondo MSZ, Filizola CLA, Barham EJ, et al.Genograma: avaliando a estrutura familiar de idosos de uma unidade de saúde da família. Rev Eletrônica de Enfermagem.2008;10(1):39-50. Disponível

em:

http: / / www.fen.ufg.br/revista/v10/n1/v10n1a04. htm .

17- Nunes MCR, Ribeiro RCL, Rosado LEFPL, Franceschini SC. Influência das características sociodemográficas e epidemiológicas na capacidade funcional de idosos residentes em Ubá, Minas Gerais. Rev bras Fisioterapia. 2009;13(5): 5-7. Disponível em: http: / / www.scielo.br/scielo.php?script=sci_arttex t\&pid=S141335552009000500003\&lng=en\&nrm=iso.

18- Hott AM, Pires VATN.Perfil dos idosos inseridos em um centro de convivência, Rev Enfermagem Integrada.2011 jul-ago;4(1): 765-78. Disponível em:http://www.unilestemg.br/enfermagemintegr ada/artigo/v4/12perfildosidososinseridosemumcen trode-convivencia.pdf .

19- Giacomin KC, Peixoto SV, Uchoa E, Lima-Costa MF. Estudo de base populacional dos fatores associados à incapacidade funcional entre idosos na Região Metropolitana de Belo Horizonte.Cad Saúde Pública.2008 jun;24(6):1260-270.

Disponível em: http://www.scielo.br/ scielo.php? script=sci_arttext\&pid=S0102311X2008000600007\& lng=pt .

20- Lebrão LL, Duarte Y. Saúde, Bem-estar e Envelhecimento - O Projeto Sabe no município de São Paulo: uma abordagem inicial. Brasília: Organização PanAmericana da Saúde, 2003.

R. pesq.: cuid. fundam. online 2013. abr./jun. 5(2):3894-03 
Louro JQ, Junior EDA, Paula FL et al.

21- Farinasso ALC. Perfil dos idosos em uma área de abrangência da estrategia de saúde fa família[Dissertação]. Ribeirão Preto: Universidade de são Paulo;2005. Disponível em: http://www.teses.usp.br/teses/disponiveis/22/22 132/tde-11052005-114419/pt-br.php .

22- Coelho Filho JM, Ramos LR. Epidemiologia no nordeste do Brasil: resultados de inquerito domiciliar. rev saúde pública.1999 out;33(5):44553. Disponível em: http: / / www.scielo.br/scielo.php?script=sci_arttex t\&pid=S0034-89101999000500003 .

23- Brasil. Instituto Brasileiro de geografia e Estatística. Pesquisa Nacional de Amostra por domicílio 2007.Brasília:2008.

24- Lima-Costa MF, Firmo JOA, Uchôa E. A estrutura da auto-avaliação da saúde entre idosos: Projeto Bambuí. Rev Saúde Pública.2004; 38(6): 827-34. Disponível em: http://www.scielo.br/pdf /rsp/v38n6/11.pdf.

25- Szwarcwald CL, Souza-Júnior PRB, Esteves MAP, Damacena GN, Viacava F. Socio-demographic determinants of self-rated health in Brazil. Cad Saúde Pública. 2005; 21(1):54-64. Disponível em: http: / / www.scielo.br/scielo.php?script=sci_arttex t\&pid=S0102-311X2005000700007 .

26- Lima-Costa M, Barreto SM, Giatti L. Condições de saude, capacidade funcional, uso de serviços de saude e gastos com medicamentos da população idosa brasileira: um estudo baseado na pesquisa nacional de Amostra por domicilio. Cad Saúde Pública. 2003; 19(3):735-43. Disponível em: http: / / www.scielo.br/scielo.php?script=sci_arttex t\&pid=S0102-311X2003000300006 .

27- Rozenfeld, S. Prevalência, fatores associados e mau usoo de medicamentos entre os idosos: uma revisão. rev saúde pública.2003;19(3):717-24. Disponível em: http://www.scielo.br/ scielo.php? pid=S0102-311X2003000300004\&script=sci_arttext.

R. pesq.: cuid. fundam. online 2013. abr./jun. 5(2):3894-03
Investigating the aged...

28- Comitê Do Consenso, Segundo consenso de Granada sobre problemas relacionados com medicamentos. Ars Pharm.2002;43(3-4):175-84. Disponível em: http://www.ugr.es/ ars/abstra ct/43-179-02.pdf .

29- Brasil, Ministério Da Saúde. Datasus. Informações de saúde, 2004. Disponivel em: www.datasus.gov.br acessado em 21/10/2012 as $12: 14 \mathrm{hrs}$

30- Campo VL, Carvalho I. Estatinas hipolipêmicas e novas tendências terapêuticas. Quim. Nova.2007;30(2):425-30. Disponível em: http: / / www.scielo.br/scielo.php?pid=S0100404220 $07000200033 \&$ script=sci_arttext .

31. Brasil. Ministério da Saúde. Departamento de Informação e Informática do Sistema Único de Saúde (DATASUS). Informações sobre mortalidade e informações demográficas. [on line]. Disponível em: http://tabnet.datasus.gov.br/cgi/tabcgi.

Acessado em 23/11/2012 as 14:20hrs.

32- Matos MFD, Silva NAS, Pimenta AJM. Prevalência dos fatores de risco para doença cardiovascular em funcionários do Centro de Pesquisas da Petrobrás. Arq Bras Cardiol. 2004;82(1):1-4. Disponível em: http://www.scielo $. \mathrm{br} / \mathrm{pdf} / \mathrm{abc} / \mathrm{v} 82 \mathrm{n} 1 / \mathrm{a} 01 \mathrm{v} 82 \mathrm{n} 1 . \mathrm{pdf}$.

33- Tinetti ME, Speechly M, Ginter SF. Risck factor for fall among elderly persons living in the community. N Engl J Med. 1988;319(26):1701-707. Disponível em: http://www.ncbi.nlm. nih.gov/pubmed/3205267 .

34- Perracini MR, Ramos LR. Fatores associados a quedas em um coorte de idosos residentes na comunidade. rev Saúde Pública. 2002; 36(6):709-

16. Disponível em: http://www.scielo.br/ scielo.php?script=sci_arttext\&pid=S0034-

89102002000700008.

35- Pereira S,Buksman S, Perracini MPYL, Barreto KML, Leite VMN. Quedas em idosos. Projeto Diretrizes. Associação Med Bras e Conselho Fed de 
Louro JQ, Junior EDA, Paula FL et al. Investigating the aged...

Med Soc Bras de Ger e Geron ,2001. Disponível em: http://www.bibliomed.com.br/diretrizes/ pdf/quedas_idosos.pdf.

36- Parra EK, Stevens JUS. Fall Prevention Programs for seniors. National Center for Injury Prevention and Control. Georgia;2000.

Received on: 16/01/2013

Required for review: 28/01/2013

Approved on: 20/02/2013

Published on: 01/04/2013

R. pesq.: cuid. fundam. online 2013. abr./jun. 5(2):3894-03 